\title{
Polonius in Shakespeare's Hamlet: A Conspirator or a Victim
}

\author{
Sameer Al-Shraah ${ }^{1}$ \\ ${ }^{1}$ Al al-Bayt University, Mafraq, Jordan \\ Correspondence: Sameer Al-Shraah, Al al-Bayt University, Mafraq, Jordan. \\ Received: August 25, 2018 Accepted: September 19, 2018 Online Published: November 28, 2018 \\ doi:10.5539/ells.v8n4p77 URL: https://doi.org/10.5539/ells.v8n4p77
}

\begin{abstract}
Critical discourse on Shakespeare's Hamlet often discusses Polonius as a victim, ignoring Shakespeare's creativity in depicting the complexities of the human psyche. Therefore, this paper attempts to study Polonius' character from a new perspective through answering questions such as: what is the meaning of the death of a whole family that has apparently nothing to do with the death of Old Hamlet? And why would this family give the first death in the play, if the family, or Polonius in particular, is not part of the conspiracy against Old Hamlet?
\end{abstract}

Keywords: Shakespeare, Hamlet, Polonius, victim, conspiracy

\section{Introduction}

critical discourse on Shakespeare's Hamlet often depict Polonius as a victim and as an innocent fool who could not embody the complexities of a conspirator, ignoring Shakespeare's genius in depicting the two opposing worlds of reality and appearance. Thus, it is dangerous to label Shakespeare's characters, such as "fool" or "victim", because these categories overlap in the world of the Shakespearean drama. This paper attempts to study Polonius' character from a new perspective through answering questions such as: what is the meaning of the death of a whole family that has apparently nothing to do with the death of Old Hamlet? And why would this family give the first death in the play, if the family, or Polonius in particular, is not part of the conspiracy against Old Hamlet? Here is some literature reviews that shows how critical discourse on Shakespeare's Hamlet often depict Polonius as a victim.

\section{Literature Review}

However, critical discourse on Shakespeare's Hamlet often depict Polonius as a victim and as an innocent fool who could not embody the complexities of a conspirator, ignoring Shakespeare's genius in depicting the two opposing worlds of reality and appearance. Thus, it is dangerous to label Shakespeare's characters, such as "fool" or "victim", because these categories overlap in the world of the Shakespearean drama. For instance, Oakes takes it for granted that Polonius plays the role of the fool of the play when he says: "He is suited for this role because of his incarnation of the fool, the one traditionally chosen as a substitute for the king in ritual" (106). This is, in fact, the most common viewpoint or interpretation of Polonius's character but not necessarily the only possible one. In his article, "Hamlet and the Security of the South African State", Martin Orkin argues that "Shakespeare's first audience would recognize in Polonius' predilection for such commonplace expressions of worldly wisdom a mind that runs along conventional tracks, sticking only to what is practically useful in terms of worldly self-advancement" (179). In other words, Orkin believes that Shakespeare gives Polonius the conventional role of a fool. However, this research argues that such characterization of Polonius is simplistic and reduces the complexity of Shakespeare's creativity.

Many other literary critics follow the same trend of depicting Polonius as being the Shakespearean fool of the play. They overemphasize their belief in the fact that Polonius is a fool just because of his foolish dialogue and utterances throughout the play while neglecting the fact that Polonius shows his wisdom and cleverness in many other situations. Just because Polonius believes that what caused Hamlet's madness is Ophelia's rejection, R. S. White judges Polonius's thinking as an act of foolishness. He states: "but when saying that it is simply Ophelia's rejection that has made Hamlet mad, he is ignorant of the predisposed mental state of the young man caused by his mother's remarriage, the recent encounter with the ghost and the whole repressive machinery of Denmark's social and political life" (White 67). Yet, White skips the fact that Polonius could be a shrewd conspirator who uses his foolishness as a cover to take the attention of others away from his participation in plotting against old 
Hamlet.

Even with Hamlet's constant insults against Polonius, critics insist on interpreting Polonius submissiveness as an act of foolishness. Indeed when Hamlet describes Polonius as a "fishmonger" (II. ii. 190), he is implying that he senses Polonius's involvement in conspiratorial deeds. Instead, scholars, like Leo Kirschbaum, explain that the aim of such insults by Hamlet is to show Polonius as a fool to the audience. He explains: "A fishmonger is a barrel, one who employs a prostitute for his business. Hamlet is obliquely telling the old councilor that he is using his own daughter for evil ends" (Kirschbaum 86). By the same token, Martin Dodsworth interprets Polonius's acceptance of Hamlet's insults and his insistence on the theory that Hamlet is mad because of his love to Ophelia as showing Polonius's foolishness. He explains: "Polonius accepts the bad treatment meted out to him as that of a man who is out of his mind: 'How say you by that? Still harping on my daughter. He is far gone"" (Dodsworth 100). Indeed what Hamlet senses about Polonius's real character could be absolutely different from the traditional criticism written on Shakespeare's Hamlet.

Although critics generally refer to Polonius's cleverness and shrewdness, yet they in no way associate these qualities with the essential characteristics and traits of a conspirator. Rather, they associate them with the qualities of traditional wise fools prevalent in Shakespearean drama. In spite of accepting Polonius to serve as Hamlet's foil, Bert States insists that he represents the fool antagonist: "Polonius is not only the perfect foil for Hamlet's wit (since irony is the mortal enemy of the order prone mind), but a shadow of Hamlet as well. Indeed, Polonius literally shadows Hamlet, or tails him and in shadowing him falls into a thematic parody of his own habits" (States 116). However, to serve as a foil to Hamlet, who embodies the typical qualities of a tragic hero, this research proposes that Polonius must represent the rival opposing qualities of a protagonist. If this theory is approved, then neither Polonius foolishness, nor Hamlet's murdering of him are accidental.

\section{Analysis}

Polonius is the first character killed in Shakespeare's Hamlet by Hamlet himself, followed by his daughter, Ophelia, who drowns herself in a brook and his son, Laertes, who dies in a duel when he seeks revenge for Hamlet's killing of Polonius, whom he assumingly mistakes for Claudius, spying on him from behind the curtain. Is the death of Polonius's whole family a mere accident, taking into consideration the genius of Shakespeare who leaves little or no place for accidents in his plays? I posit that the death of Polonius and his family is not accidental and that it has to do with Polonius's being accomplice, to a certain degree, in King Claudius's plot against his brother. The death of Polonius and his family constitutes half of the deaths in Hamlet, if we exclude the killings of the two messengers, Rosencrantz and Guildenstern, who are killed in England, not Denmark.

The question to ask is: what is the meaning of the death of a whole family that has apparently nothing to do with the death of Old Hamlet? And why would this family give the first death in the play, if the family, or Polonius in particular, is not part of the conspiracy against Old Hamlet? The deaths occur in a sequence of a man [Polonius], a woman [Ophelia], and finally a man [Laertes]. I dare contend that it is not by mistake that Hamlet kills Polonius who is hiding behind the curtains in Gertrude's room despite the fact that Hamlet knows the voice of Polonius very well as he hears him crying in pain "O, I am slain!" (III.iv.25), and Hamlet further asks his mother "Is it the king?"(III.iv.28). What supports this theory is the fact that Hamlet has the chance to kill his uncle while he is kneeling for prayers well before the exchange between Hamlet and his mother. Hamlet's weak claim is that if he kills Claudius while praying, this will give him access to heaven.

Polonius's past is not revealed in the text. The only thing we know is that he is the closest aide to King Claudius. We don't know for sure if he was also a counselor to Old Hamlet. This knowledge about the man's past is crucial in determining the fact about the conspiratorial role, if any, which he plays, as he would most likely know something about the conspiracy, if we assume that he was also Lord Chamberlain in Old Hamlet's reign as he is now to King Claudius. Because we are not given textual evidence of the aforementioned assumption, it is best to establish the personality of Polonius based on conduct in regard to all events in Hamlet.

Shakespeare's true voice is given through Hamlet more than any other character in the play. Hamlet refers to Polonius as a "tedious old fool" (II.ii.215), and a "fishmonger" (II.ii.175). What does Shakespeare want the audience to think of this key advisor to King Claudius? Some might believe that the character of Polonius in Shakespeare's Hamlet is nothing but a minor entertainer, voicing superficial and shallow wise insights. It is the same man who in an exchange with his son Laertes who is preparing to go for his studies in Paris, speaks absolute wisdom. Polonius in that famous exchange tells his son: "To thine own self be true" (I.iii.78). The truth is that Polonius has great philosophical depth and insight into both himself and the minds of the other characters in the play. The eloquent speeches by Polonius is Shakespeare's way of telling us that Polonius is not just a simple advisor with a tendency towards egotism, but an oddly complex, well-rounded man that we have, as 
audience and readers, to beware when analyzing his role in the play.

Perhaps Polonius's sometimes foolish behavior is simply a clever trick on his part, or on the part of Shakespeare, which gives him the ability to catch people off guard when they are defenseless in his presence. Perhaps he does not want King Claudius to feel that one of his closest subordinates is wiser than he is, because Polonius knows that this would cost him his position in the court as Lord Chamberlain. Regardless of his motives, Polonius can in no logical way be described as an uncomplicated minor character in Shakespeare's Hamlet.

I will analyze seven pieces of evidence that may be used as bases to implicate Polonius, in variable degrees, in the conspiracy. Those seven points are in parts traits and properties of Polonius and some are actions that he does that make him a potential conspirator in Claudius heinous murder of Old Hamlet. First, he seems to enjoy as well as excel in spying. He loses his life voluntarily spying on Hamlet as a favor to King Claudius. He also sends Reynaldo to spy on his son, Laertes, at his school in France:

Marry, well said; very well said. Look you, sir,

Inquire me first what Danskers are in Paris;

And how, and who, what means, and where they keep,

What company, at what expense; and finding

By this encompassment and drift of question

That they do know my son, come you more nearer

Than your particular demands will touch it:

Take you, as 'twere, some distant knowledge of him;

As thus, "I know his father and his friends,

And in part him.” Do you mark this, Reynaldo? (II.i.6-15)

Polonius's personality is secretive, observant, and skeptical. He addresses Reynaldo: "Observe his inclination in yourself" (II.i.71). He does not trust others, even if they are his closest family members. A man with such propensity to gather intelligence information about his son is hard to be deceived and avoided by Claudius and Gertrude when planning the plot on Old Hamlet's life. This fosters the theory of his involvement in, or at least knowledge of, the murder of Old Hamlet. A man of such inquisitive and clandestine personality is a potential participant in any dubious activity in the court where he is so close to the monarch.

The second point to take into consideration is Polonius's sheer interference in the private life of his daughter Ophelia. He treats her as a pawn and warns her against Hamlet's advancements towards her. He seems to consider Hamlet as part of the opposite camp, if we consider Polonius on the camp of Claudius and Gertrude. He advises Ophelia not to believe Hamlet's claim of love:

Polonius: What, have you given him any hard words of late?

Ophelia: No, my good lord. But, as you did command

I did repel his letters and denied

His access to me.

Polonius: That hath made him mad. (II.ii.105-110)

He orders her to give less of her time to Hamlet in the future, saying, "From this time, daughter, / Be somewhat scanter of your maiden presence" (I.iii.120-121). Ophelia tells her father she will do what he commands: "I shall obey, my lord" (I.iii.136). Laertes warns Ophelia to beware of Hamlet. He tells her that Hamlet is insincere in his love "For Hamlet and the trifling of his favour, / Hold it a fashion and a toy in blood, / ...sweet not lasting" (I.iii.5-6, 8). Laertes then instructs the submissive Ophelia, telling her that Hamlet will say anything to win her heart. He tells her to hold off, and if Hamlet still loves her after he has been made king, only then should she consider marrying him. Ophelia agrees to remember what he has told her. The whole family seems to harbor a grudge towards Hamlet who has done nothing wrong to them so far. Polonius questions Ophelia about her relationship with Hamlet. Polonius deals in a double-standard manner with his son and daughter. We see Polonius kind and jovial with Laertes, rough, cruel, and obscene with his daughter Ophelia. He calls her naïve, orders her not even to talk to Hamlet, and demands to see his love letters to her. Polonius shouts at Ophelia, “Affection! Pooh! You speak like a green girl ... Do you believe his tenders, as you call them?" (I.iii.101-103).

Hamlet is in face of a great dilemma where almost all characters in the play are against him. In his article, "The 
Embassy of Death: An Essay on Hamlet", Wilson Knight explains that creatures collaborate to work against Hamlet who is already in an unenviable situation:

Instinctly the creature of earth, Laertes, Polonius, Ophelia, Rosencrantz, and Guildenstern, league themselves with Claudius: they are of his kind. They sever themselves from Hamlet. Laretes sternly warns Ophelia against her intimacy with Hamlet, so does Polonius. They are, in fact, all leagued against him, they are puzzled by him or fear him; he has no friend except Horatio. (190)

Third, interestingly enough, Polonius is the first character that describes Hamlet as a mad man. He tells King Claudius and Queen Gertrude that Hamlet is mad:

..., since brevity is the soul of wit,

And tediousness the limbs and outward flourishes,

I will be brief: your noble son is mad:

Mad call I it; for, to define true madness,

What is't but to be nothing else but mad?

But let that go. (II.ii.90-95)

They both become impatient to hear what he is saying, and Polonius finally produces a letter from Hamlet to Ophelia in which Hamlet confesses his love to her. Gertrude then asks Polonius how Ophelia received Hamlet's proposition of love. Polonius is forced to tell them that at his request she ignored Hamlet or rebuked his love. Claudius is not completely convinced that this is the full cause of Hamlet's insanity. This leads us to the fourth incident that proves that Polonius is haunted with suspicion and secrecy; spying again. Polonius suggests to the king putting Ophelia into the hall where Hamlet is known to spend hours strolling each day. They plan to hide behind a tapestry and watch what happens. They overhear Hamlet addressing Ophelia:

If thou dost marry, I'll give thee this plague for thy dowry: be thou as chaste as ice, as pure as snow, thou shalt not escape calumny. Get thee to a nunnery, go: farewell. Or, if thou wilt needs marry, marry a fool; for wise men know well enough what monsters you make of them. To a nunnery, go, and quickly too. Farewell. (III.i.134-140)

Hamlet continues rebuking Ophelia, pretending to be mad as he senses that some people are spying on him. His attitudes regarding Ophelia become harsher and sterner. John Wilson, in his article, "Hamlet and Ophelia", contends that "Hamlet's accidental discovery of the intention to spy upon him has a bearing much wider than his attitude towards Ophelia ... it constitutes the mainspring of the events that follow in acts 2 and 3" (197). Indeed, we see that after his exchange with Ophelia, Hamlet starts to act upon his insanity as a means to exact his revenge by pretending to be out of rationality so as to fully maturate his ultimate plan to get even with his opponent(s). He delves more into berating Ophelia to mislead the eavesdroppers:

Go to, I'll no more on't; it hath made me mad. I say, we will have no more marriages: those that are married already, all but one, shall live; the rest shall keep as they are. To a nunnery, go. (III.i.146-150)

Hamlet continues to berate Ophelia severely as if he knows that he is being watched closely. William Hazlitt, in his article, "Characters of Shakespeare's play: Hamlet", explains that Hamlet's behavior towards Ophelia is natural and excusable taking into consideration his circumstances:

His conduct to Ophelia is quite natural in his circumstances. It is that he assumed severity only. It is the effect of disappointed hope, of bitter regrets, of affection suspended not obliterated, by the distractions of the scene around him! Amidst the natural and preternatural horror of his situation, he might be excused in delicacy from carrying on a regular courtship. (167)

It would be a mistake to take Polonius for a simple courtier whose only aim is to please the king. Polonius searches for cause and reason behind actions. His uncovering of the reason behind Hamlet's madness does not suffice: "I have found / The very cause of Hamlet's lunacy" (II.ii.48-49). He does not simply accept facts as abstract facts, he seeks to discover the truth on his own by verification and cross examination. He follows a systematic scientific methodology of theory and proof. He goes into great length about Hamlet's madness and its relation to love and truth. He then seeks to "try out" his theories by testing Hamlet's sanity through a sequence of questions. These are not the actions of a simple man, but actions of an astute human being, pending on theorizing, methodically proofing, and refining his findings. He must have motives to further alienate Hamlet who is the next heir to the throne of Denmark. Although no textual evidence is given, Polonius might have in mind preparing his son, Laertes, for the throne with the absent of a direct heir to the throne in case Hamlet is really 
implicated in madness. This theory may be the fifth point that indicates conspiratorial aspects in the personality of Polonius whom Shakespeare genuinely characterized as a man of minor role in the play.

During the exchange between Hamlet and Ophelia, Hamlet abruptly asks her, "Where's your father?" (III.i.30). This question carries many meanings and lends itself to many analyses. I opt for explaining this question as an indication that Hamlet knows that he is being watched by Polonius and Claudius. Hamlet insists on his madness by showing his lack of affection to Ophelia, who he truly loves, in order to further trick all people, especially his mother and uncle that he is really mad. Shakespeare is constrained by the original Hamlet story to have Hamlet pretend to be comically insane and for the king to try to find whether he is really crazy or just faking. But Hamlet is also distraught, and the play is largely a study of his emotional turmoil while he is forced to endure a rotten environment and a tortured mind over his father's death. We might well pose the idea that Hamlet, knowing that his behavior is going to be abnormal because he is under stress, wants to mislead the court and people around him into thinking he is simply mad rather than bent on revenge.

What rules out Hamlet's insanity is the fact that he is as rational as anyone else is, even more than any character in the play, when he is around his only true friend Horatio. Hamlet expresses his trust and faith in Horatio when he says: "Horatio, thou art e'en as just a man / As e'er my conversation coped withal" (III.ii.46-47). Hamlet speaks with very rational thoughts as he tells Horatio "Observe mine uncle. If his occulted guilt / Do not itself unkennel in one speech, / It is a damned ghost that we have seen, / And my imaginations are as foul / As Vulcan's stithy" (III.ii.73-77). He only changes his behavior on the surface so that others-Claudius, Gertrude, Rosencrantz, Guildenstern, Polonius, and Ophelia - will really think his madness is driven by a particular motive [his love for Ophelia]. In this case, Hamlet is free to act irrationally and assert his real opinions about everyone.

The sixth piece of evidence that might implicate Polonius in the conspiracy is the fact that Polonius suggest to the king that he will not leave Hamlet alone with his mother in her room because, as he contends, nature makes of them (Gertrude and her son, Hamlet) one entity. He again volunteers to spy on behalf of King Claudius. Polonius instructs Queen Gertrude on how to behave with Hamlet, at the opening of the scene in her closet, during which Hamlet kills Polonius:

He will come straight. Look you lay home to him:

Tell him his pranks have been too broad to bear with,

And that your grace hath screen'd and stood between

Much heat and him. I'll sconce me even here.

Pray you, be round with him. (III.iv.1-5)

Hamlet kills Polonius apparently by mistake, but he thinks that he is doing God's will concerning those who wronged him and his father, Old Hamlet. He is also a Christian prince, instilled and raised with true Christian beliefs, teachings, and moral standpoints. When the ghost tells the young prince that he must seek revenge, the request of course shocks young Hamlet. He fears having to be the judge of a man, and if he kills Claudius, that is passing judgment on his soul. According to the Christian faith, passing judgment on and murdering a fellow man are two of the most abhorred sins. He ponders and weighs his decision to exact revenge long enough to be sure that he is executing a divine sentence on sinners and conspirators. Therefore, Hamlet must overcome his moral sensitivities if he wants to kill Claudius, which means he must prepare for the perfect time to perform his deed. As a result, Hamlet prepares himself to take the king's life by waiting for Claudius's sins to accumulate. Thus, only when the perfect moment shows itself, will Hamlet act. As killing Polonius is the first real action, Hamlet contemplates and addresses his mother:

I do repent: but heaven hath pleased it so,

To punish me with this and this with me,

That I must be their scourge and minister.

I will bestow him, and will answer well

The death I gave him. So, again, good night.

I must be cruel, only to be kind:

Thus bad begins and worse remains behind.

One word more, good lady. (III.iv.173-180)

The aforementioned lines are of the most poetic quoted lines in Shakespeare. They show a start of the active role 
Hamlet is about to unleash. He now sets his goal as an instrument of divine punishment. In his article, "Hamlet as a Minister and Scourge", Fredson Bowers contends that:

From the Elizabethan point of view, divine providence works out the catastrophe with justice. The plotters are hoist by their own villainous schemes; and then, triumphantly, the opportunity is given Hamlet to kill Claudius in circumstances which relieve him from immoral penalty for blood. (91)

Hamlet's repentance does not seem to be brought about because he killed an innocent man. It is clear that Hamlet harbors some grudge against Polonius as he describes him: "Indeed this counselor / Is now most still, most secret and most grave, / Who was in life a foolish prating knave" (III.iv.213-215). Does Hamlet have definite evidence that Polonius is part of the political conspiracy against his father? Shakespeare will not tell us that, but Hamlet's action and remarks against Polonius surely indicate some threads in that direction. It is Shakespeare the genius in characterization that unleashes our minds to carefully take into consideration every word in his works and not to rule out any possibility of explaining the motives and action of his characters regardless of the size they occupy in his dramatic masterpieces.

The seventh and last piece of evidence that implicates Polonius is a very clear indication that Hamlet knows that the person hiding behind the arras is Polonius and he killed him because he is an accomplice to his uncle, Claudius. Hamlet dubs Claudius many bad names such as "a murderer", "a villain", and "a coward", but interestingly enough, Hamlet never calls his uncle "a rat". This means that Hamlet is sure that the person spying on him is not Claudius, and that he is Polonius. He calls Polonius "a rat" which clearly indicates that he is spying for King Claudius for a worthless amount of money "a ducat". Hamlet exclaims: "How now, a rat? / Dead for a ducat, dead!" (III.iv.23-24). We can assume that Hamlet in killing the hiding person, knows that the spy is commissioned by King Claudius and this puts the two, Claudius and the spy (Polonius), in the same rank as conspirators.

As I previously showed the conduct of Polonius towards Hamlet, let me now show how Hamlet treats Polonius. In the first meeting of the two men, Hamlet mocks Polonius. Hamlet makes fun of the man by repeating Polonius's own words. Polonius comes to Hamlet as he is preparing for his play and says: "My lord, I have news to tell you" (II.ii.366), and strangely enough, Hamlet responds: "My lord, I have news to tell you" then added a question: "When Roscius was an actor in Rome?"(II.ii.367-368). After that Hamlet indirectly points to Polonius's daughter, Ophelia, and compares Polonius to the wise of Israel, Jephthah. The story of Jephthah recorded in the book of Judges. Jephthah is about to wage a major battle against the Ammonites. Before going to battle, Jephthah makes a vow to God that he will offer his daughter to the first man who greets him back from his victory at his house:

And Jephthah vowed a vow unto the Lord, and said, "If thou shalt without fail deliver the children of Ammon into mine hands, then it shall be, that whatsoever cometh forth of the doors of my house to meet me, when I return in peace from the children of Ammon, shall surely be the Lord's, and I will offer it up for a burnt offering." (The Holy Bible: KJV, Judges 11:23-37)

It is clear that Hamlet does not respect Polonius right from the beginning of their association. Hamlet is indirectly accusing Polonius of treating his daughter as a commodity where he and his son, Laertes, control her and force her not to accept Hamlet's love. Hamlet might know, through his mother probably, that this man is part of the plot against his father. Hamlet's comparing Polonius to Jephthah who sells his daughter is very humiliating. We cannot assume that Hamlet is mocking and humiliating the father of the girl he loves for no reason at all. Hamlet, with his sharp mind, senses that Polonius is not as honest as he wants all people around him to think he is. Hamlet is aware of the bad intentions of Polonius as it is shown later when Polonius is the first, and may be the only, person who accuses Hamlet of insanity.

Whether Polonius takes part in the planning and execution of the conspiracy against Old Hamlet or just knows about it and holds backs information remains mystery as the text does not explicitly show the degree of Polonius's involvement. Yet this paper tries to show that one of the two previously mentioned possibilities is in fact likely. I have shown that Polonius is not a mere victim of incidents along with his family. He sure has part in the conspiracy. Our new reading of Polonius is to take into consideration that he is a highly astute and erudite politician who has a strong sense of observation and a deep inclination into curiosity and investigation as apparent in his spying and analytical abilities that he shows all along the course of Shakespeare's masterpiece, Hamlet. Again, Shakespeare has no place for incidents; every thing is planned and well intended in his works. I have provided seven "ambiguities" or pieces of evidence that point to the conspiratorial part Polonius might have played in the murder of Old Hamlet as well as his relentless effort to render Hamlet insane so as to save King Claudius as well as reserve his position of privilege as a close counselor to the king and a key player in the 
political arena in Denmark.

\section{Conclusion}

Whether Polonius takes part in the planning and execution of the conspiracy against Old Hamlet or just knows about it and holds backs information remains mystery as the text does not explicitly show the degree of Polonius's involvement. Yet this paper tries to show that one of the two previously mentioned possibilities is in fact likely. I have shown that Polonius is not a mere victim of incidents along with his family. He sure has part in the conspiracy. Our new reading of Polonius is to take into consideration that he is a highly astute and erudite politician who has a strong sense of observation and a deep inclination into curiosity and investigation as apparent in his spying and analytical abilities that he shows all along the course of Shakespeare's masterpiece, Hamlet. Again, Shakespeare has no place for incidents; every thing is planned and well intended in his works. I have provided seven "ambiguities" or pieces of evidence that point to the conspiratorial part Polonius might have played in the murder of Old Hamlet as well as his relentless effort to render Hamlet insane so as to save King Claudius as well as reserve his position of privilege as a close counselor to the king and a key player in the political arena in Denmark.

\section{References}

Bowers, F. (1968). Hamlet as a Minister and Scourge. In D. Bevington (Ed.), Twentieth Century Interpretations of Hamlet; A Collection of Critical Essays (pp. 82-92). Englewood Cliffs, N.J.: Prentice-Hall, Inc.

Grebanier, B. (1960). The Heart of Hamlet. New York: Thomas Y. Cromwell Co.

Hartwig, J. (1971). Parodic Polonius. Texas Studies in Literature and Language, 13.

Hazlitt, W. (1963). Characters of Shakespeare's play: Hamlet. In C. Hoy (Ed.), Hamlet (pp. 163-169). New York: W. W. Norton \& Company, Inc.

Kirschbaum, L. (1962). Character and Characterization in Shakespeare. Detroit, Wayne State UP.

Knight, W. (1963). The Embassy of Death: An Essay on Hamlet. In C. Hoy (Ed.), Hamlet (pp. 185-193). New York: W. W. Norton \& Company, Inc.

Oakes, E. (1994). Polonius, the Man behind the Arras: A Jungian Study. New Essays on Hamlet. New York: AMS Press.

Orkin, M. (1995). Hamlet and the Security of the South African State. Critical Essays on Shakespeare's Hamlet. New York: G.K. Hall and Co.

Shakespeare, W. (1990). The Tragedy of Hamlet, Prince of Denmark. Chicago: Harcourt Brace Jovanovich, Inc.

States, B. O. (1992). Hamlet and the Concept of Character. Baltimore: John Hopkins UP.

The Holy Bible: King James' Version. (2004). New York: Barbour Publishing, Inc.

Wilson, J. (1963). Hamlet and Ophelia. In C. Hoy (Ed.), Hamlet (pp. 193-197). New York: W. W. Norton \& Company, Inc.

\section{Copyrights}

Copyright for this article is retained by the author, with first publication rights granted to the journal.

This is an open-access article distributed under the terms and conditions of the Creative Commons Attribution license (http://creativecommons.org/licenses/by/4.0/). 